\title{
Organic chemistry basic concepts teaching in students of large groups at Higher Education and Web 2.0 tools
}

La enseñanza de conceptos básicos de química orgánica y las herramientas Web 2.0 en grupos masivos a nivel universitario

\author{
Volumen 19, Número 1 \\ Enero-Abril \\ pp. 1-31
}

Este número se publica el 1 de enero de 2019

DOI: 10.15517/aie.v19i1.35589

\author{
Rosaura M. Romero \\ Leonidas O. Vidal Espinosa \\ Darinka Ramírez Hernández
}

Revista indizada en REDALYC, SCIELO

Revista distribuida en las bases de datos:

LATINDEX, DOAJ, REDIB, IRESIE, CLASE, DIALNET, SHERPA/ROMEO, QUALIS-CAPES, MIAR

Revista registrada en los directorios:

ULRICH'S $, \underline{R E D I E}, \underline{\text { RINACE}}, \underline{\text { OEI}}, \underline{\text { MAESTROTECA, PREAL, }}$ 


\title{
Organic chemistry basic concepts teaching in students of large groups at Higher Education and Web 2.0 tools
}

La enseñanza de conceptos básicos de química orgánica y las herramientas Web 2.0 en grupos masivos a nivel universitario

\author{
Rosaura M. Romero' \\ Leonidas O. Vidal Espinosa² \\ Darinka Ramírez Hernández ${ }^{3}$
}

\begin{abstract}
A large group together with the fact that organic chemistry is commonly regarded as difficult creates challenges for the instructor. In this paper we describe the evaluation of the effectiveness of implementing Web 2.0 tools in organic chemistry lecture on students' understanding of basic concepts in comparison with the absence of such tools in large groups. The study used a mixed method design that encompassed 537 students in six separate sections of two courses, four accelerated and two general organic chemistry courses. All the sections but three experienced the standard lecture environment without intervention. The intervention consisted of a blog designed specifically for this research, which used entries regarding key concepts with selected videos. Instructors and students were invited to respond to various instruments for research data gathering. Those instruments included questions concerning previous knowledge of chemistry, covered information to acknowledge the use of Web 2.0 by instructors and students, and involved items to discover whether the tools were perceived useful for the students. The study used only data from the students who attended class on a regular basis and completed the test and the questionnaires. The impact of the use of Web 2.0 on student achievement was obtained from the students' grades on the first examination of the term. The participants' perception was that the tools are useful for the teaching-learning process and the blog and videos had a positive impact on their academic performance.
\end{abstract}

Keywords: second-year undergraduate, internet/web-based learning, organic chemistry.

Resumen: Un grupo grande y el hecho de que la química orgánica generalmente se considera un tema difícil ocasionan desafíos para la persona instructora. En este artículo se describe la evaluación de la efectividad del uso de herramientas Web 2.0 en las clases de química orgánica para apoyar la comprensión de conceptos básicos por parte del estudiantado, en comparación con la ausencia de ellas. El estudio utilizó un diseño mixto que abarcó a 537 estudiantes en cuatro grupos de Fundamentos de química orgánica y en dos de Química orgánica general. Todos los grupos, excepto tres, experimentaron el ambiente estándar de la clase sin intervención. La intervención consistió en un blog diseñado específicamente para esta investigación, el cual contenía videos sobre conceptos clave. Tanto instructores como estudiantes fueron invitados a responder diversos instrumentos para la recolección de datos. Dichos instrumentos incluyeron preguntas sobre conocimientos previos de química e información sobre el uso de Web 2.0 por parte de instructores y estudiantes. Asimismo, se incluyeron consultas para descubrir si las herramientas eran percibidas como útiles. El estudio utilizó solo datos del estudiantado que asistió a las lecciones de forma regular y completó la prueba y los cuestionarios. El impacto del uso de Web 2.0 en el rendimiento estudiantil se valoró con las calificaciones obtenidas en el primer examen del semestre. La percepción de las personas participantes fue que las herramientas son útiles para el proceso de enseñanza-aprendizaje y que el blog y los videos tuvieron un impacto positivo en su desempeño académico.

Palabras clave: estudiantes universitarios, aprendizaje mediante internet, química orgánica.

1 Universidad de Costa Rica, Escuela de Química y Centro de Investigaciones en Productos Naturales (CIPRONA), San José, Costa Rica.Dirección electrónica: rosaura.romero@ucr.ac.cr

2 Universidad Autónoma de Santo Domingo, Escuela de Química. Santo Domingo, República Dominicana. Dirección electrónica: o-vidal@hotmail.com

${ }^{3}$ Tecnológico de Monterrey, Departamento de Ingeniería Química. Monterrey, Nuevo León, México. Dirección electrónica: darinka@itesm.mx

Artículo recibido: 31 de marzo, 2018

Enviado a corrección: 20 de julio, 2018

Aprobado: 10 de diciembre, 2018 


\section{Introduction}

Large groups pose challenges even for the most experienced lecturer and unfortunately, the instructors continually see the size of their courses increase because of the increment on the undergraduate enrolments and strained instructional budgets. How to encourage an attractive and efficient learning experience for all the students? How to overcome the belief that Organic Chemistry is an impossible subject and this myth passed on from generation to generation? There are no simple answers for these questions.

A course must be designed to fit the diverse learning approaches of students and to overcome the difficulties related to insufficient motivation, lack of confidence, negative expectations, a sense of anonymity in large groups and any other factor detrimental to the teaching-learning experience. According to Chickering and Gamson (1987), guidelines and strategies to improve teaching and learning include (1) encouraging contact between students and instructors, (2) encouraging cooperation among students, (3) encouraging active learning, (4) providing prompt feedback, (5) emphasizing time-on-task, (6) communicating high expectations, and (7) respecting diverse talents and ways of learning. Even though almost 30 years have passed since these seven principles were enunciated, they remain adequate to evaluate and improve learning (Dunlap and Lowenthal 2018; Johnson 2014; Lenert and Janes 2017).

The advancement in information and communication technologies (ICT) caused the creation of new web-based tools, known as Web 2.0, and these applications may facilitate strategies to improve teaching and learning. Facebook, Twitter, wikis and blogs, among others Web 2.0 applications, are used in higher education to mediate and enhance the instruction and promote active learning because they allow users to collaborate, contribute and to publish their thoughts (Tess, 2013). Such tools afforded new ways for innovative educational approaches and support the strategies suggested by Chickering and Gamson (1987). On the other hand, the tools are popular, they are known by the students and are suitable for learning (Ulrich and Karvonen, 2011). Using tools that students find appealing can make a difference in their learning and extend it beyond university classroom.

In this research the effectiveness of learning basic organic chemistry concepts in large groups of higher education was studied by comparing the opinion and achievement of students when they were taught in a standard lecture environment and when they also used videos and a blog to support the teaching-learning process. 


\section{Theoretical framework}

\subsection{The Web 2.0 applications}

ICT comprises techniques in a group to manipulate information and thus to facilitate communication. Among the most representative of this group are communication networks such as the Internet. The Internet, or world-wide web, evolved rapidly: some authors perceived three stages or grouped its evolution as Web 1.0, Web 2.0, Web 3.0 -- and even Web 4.0 (Kose, 2015; Goodfellow and Maino, 2010). The term Web 1.0 refers to all tools through which information is disseminated in one direction, and therefore represents a passive means through which people merely seek information but have no access to creating it (Davis and Goodman, 2014). There are multiple definitions for Web 2.0 but they all have in common that it envelops diverse techniques, services and tools that enable participants to collaborate actively in the creation of content, generation of knowledge and sharing of information online (Grosseck, 2009).

The qualities of Web 2.0 applications and their popularity caused Web 2.0 to encompass techniques that are incorporated in higher education, even they were not created specifically for academic use. Applications such as Facebook, Twitter and MySpace, amongst others, are specifically identified as emerging techniques applicable to teaching and learning. They can meet various needs of student diversity, flexibility, and ubiquity, and facilitate collaboration and communication between instructors and students, also causing the latter to be responsible for their learning (Alvarez-Flores and Nuñez, 2013). Web 2.0 tools are so popular in education that it is merely sufficient to inspect the list of the top 200 Tools for Learning to realize how they dominate the list (Top 200 tools for learning, 2017).

\subsection{Web 2.0 applications in chemistry at university level}

ICT can support learning of varied types; among them active learning, constructive learning and cooperative learning. Students explore and have access to information that helps them fulfil criteria for handling components and parameters, but it is also evident that constructive learning occurs when learners can articulate what they know and learn, then reflect on its meaning and importance in a social and intellectual context. Cooperative learning might also be promoted because a student takes an active role and collaborates with others to complete his or her learning. Web 
2.0 tools are incompatible with the typical role of a passive student and a lack of interaction between the actors in education. Besides the user-centred focus of the tools, other reasons to introduce these techniques at a tertiary educational level are related to the fact that the majority young people already utilize them in their spare time, and that future employment might require competence in the use of similar techniques (Bonderup, 2009).

There are several reports in the literature regarding how Web 2.0 tools have been implemented so university students can have additional opportunities for learning environments (Table 1).

Table 1. Web 2.0 applications in chemistry at university level

\begin{tabular}{|c|c|c|}
\hline Research title & Web 2.0 tool & Reference \\
\hline $\begin{array}{l}\text { The Virtual ChemLab project: a realistic and sophisticated } \\
\text { simulation of inorganic qualitative analysis }\end{array}$ & Virtual ChemLab & $\begin{array}{l}\text { Woodfield et al. } \\
2004\end{array}$ \\
\hline $\begin{array}{l}\text { Assessing the effect of Web-based learning tools on student } \\
\text { understanding of stoichiometry using knowledge space theory }\end{array}$ & $\begin{array}{l}\text { Mastering Chemistry } \\
\text { Web (MCWeb) }\end{array}$ & $\begin{array}{l}\text { Arasasingham, } \\
\text { Taagepera, Potter, } \\
\text { Martorell and } \\
\text { Lonjers, } 2005\end{array}$ \\
\hline $\begin{array}{l}\text { The Virtual ChemLab project: a realistic and sophisticated } \\
\text { simulation of organic synthesis and organic qualitative analysis }\end{array}$ & Virtual ChemLab & $\begin{array}{l}\text { Woodfield et al. } \\
2005\end{array}$ \\
\hline $\begin{array}{l}\text { Comparing the effectiveness on student achievement of a student } \\
\text { response system versus online WebCT quizzes }\end{array}$ & WebCT & $\begin{array}{l}\text { Bunce, Vandenplas } \\
\text { and Havanki (2006) }\end{array}$ \\
\hline $\begin{array}{l}\text { Mobile and Web } 2.0 \text { technologies in undergraduates science: } \\
\text { situating learning in everyday experiences }\end{array}$ & Flickr & $\begin{array}{l}\text { Waycott } 2009 \text { and } \\
\text { Kennedy, }\end{array}$ \\
\hline $\begin{array}{l}\text { Effectiveness of a virtual laboratory as a preparatory resource for } \\
\text { distance education chemistry students }\end{array}$ & $\begin{array}{l}\text { Virtual Chemistry } \\
\text { Laboratory }\end{array}$ & Dalgarno et al. 2009 \\
\hline $\begin{array}{l}\text { The chemistry of Facebook: using social networking to create an } \\
\text { online community for the organic chemistry laboratory }\end{array}$ & Facebook & $\begin{array}{l}\text { Schroeder and } \\
\text { Greenbowe, } 2009\end{array}$ \\
\hline $\begin{array}{l}\text { Adapting to student learning styles: engaging students with cell } \\
\text { phone technology in organic chemistry instruction }\end{array}$ & Mobile PowerPoint & Pursell, 2009 \\
\hline $\begin{array}{l}\text { A collaborative, Wiki-based organic chemistry project } \\
\text { incorporating free chemistry software on the Web }\end{array}$ & Wikis & $\begin{array}{l}\text { Evans and Moore, } \\
2011\end{array}$ \\
\hline $\begin{array}{l}\text { ChemVoyage: A web-based, simulated learning environment with } \\
\text { scaffolding and linking visualization to conceptualization }\end{array}$ & ChemVoyage & $\begin{array}{l}\text { McRae, Karuso, and } \\
\text { Liu, F., } 2012\end{array}$ \\
\hline $\begin{array}{l}\text { Chemistry by design: a web-based educational flashcard for } \\
\text { exploring synthetic organic chemistry }\end{array}$ & Chemistry by Design & $\begin{array}{l}\text { Draghici } \\
\text { Njardarson, } 2012\end{array}$ \\
\hline $\begin{array}{l}\text { Case study using online homework in undergraduate organic } \\
\text { chemistry: results and students attitudes }\end{array}$ & $\begin{array}{l}\text { Online Homework } \\
\text { System (OHS) }\end{array}$ & $\begin{array}{l}\text { Parker and Loudon, } \\
2012\end{array}$ \\
\hline $\begin{array}{l}\text { Development and implementation of a first-semester hybrid } \\
\text { organic chemistry course: yielding advantages for educators and } \\
\text { students }\end{array}$ & $\begin{array}{l}\text { Adobe Connect and } \\
\text { Angel }\end{array}$ & Ealy, 2013 \\
\hline $\begin{array}{l}\text { Eliciting student explanations of experimental results using an } \\
\text { online discussion board }\end{array}$ & VoiceThread & $\begin{array}{l}\text { Shultz, Winschel, } \\
\text { Inglehart } \\
\text { Coppola, } 2014\end{array}$ \\
\hline
\end{tabular}

Source: Resesarcher's own design (2018) 
Woodfield et al. $(2004,2005)$ created laboratory simulations for inorganic and organic qualitative analysis, organic synthesis, quantum chemistry, gas properties, titration experiments, calorimetric and thermochemical experiments, for freshman and sophomore-level chemistry students. These simulations cannot teach a student the skills for using and manipulating equipment (the "how"), however they give them freedom to explore and help the students understand the "what", "when", and "why" of the experiments.

Dalgarno et al. (2009) also explored the effectiveness of a virtual chemistry laboratory to prepare students to deal with anxiety previous laboratory sessions. The simulated laboratories within a virtual environment were effective as tools for familiarising students with the laboratory and helped as a supplementary learning tool. Although this study was set in a distance education environment, this may be a useful approach for students before they enter a chemistry laboratory for the first time.

Shultz et al. (2014) provide an opportunity for reflective thinking about experimental results using an online discussion board. Different topics were assigned to each group of students and their responses of how they solved the problems were uploaded as audio or video files. They also participated in a peer evaluation and the student response to the activity was positive.

Other authors utilised Web-based learning tools for teaching general chemistry students. They used the software called Mastering Chemistry Web (MCWeb) as homework instruction and learning for stoichiometry subject. The students who used MCWeb performed better than the counterparts who did not, according to knowledge space theory analysis (Arasasingham et al. 2005).

Waycott and Kennedy (2009) also asked students to join a private group on Flickr web page and published at least two photographs that illustrated chemical processes. The students had to relate their formal learning about chemistry to their everyday life. They "tagged" the images with appropriate keywords, identifying how each image illustrated chemical principle, and they were also asked to review other students' photographs and captions. Most of the participants felt the activity did not enhance their learning, however some considered it worthwhile and they benefited from relating what they were learning in class to the everyday experiences and sharing knowledge with their peers. The interviewed instructors were of the opinion that the 
activity was successful and intended to use it again (Bennett, Bishop, Dalgarno, Waycott and Kennedy, 2012).

The literature shows reports of the benefits of the use of online systems for work at home (OHS). Programs such as WebAssign, WebWork, ALEKS, MathXL and ARIS are also utilized in various disciplines in science, technology, engineering and mathematics. An application of WebCT (Blackboard Inc.) was the subject of a study by Bunce, VandenPlas and Havanki (2006). The aim of their research was to assess whether online tests with WebCT and in classrooms with the use of interactive response systems (Student Response System, SRS), had an effect on the student performance according to the four-hour examination performed in the course and the standardised test from the American Chemical Society Exams Institute. They found that the use of tests with WebCT had a positive effect on student performance on the written examination of the course but not on the ACS exam. The authors suggested that due to time constraints, the students used tests to prepare only for the course assessments but not for the ACS exams. Overall, more benefit was attributed to the completion of practice tests outside class because the student might have immediate feedback and they undertook the evaluation at a time convenient for them.

In the specific case of organic chemistry, Parker and Loudon (2013) mentioned that the incorporation of OHS is slow, likely because of lack of flexibility of the systems to incorporate the drawing of chemical structures and the representation of mechanisms with arrows. There are, however, other systems that incorporate these initial shortcomings: EPCH/ACE system at University of Kentucky, the CAN model (curved arrow neglect) used at University of West Virginia, Explorer Synthesis at University of California, Irving and Learning Sapling 4 . The objective of that research of Parker and Loudon was to assess the impact and the perception of students when they used the Sapling Learning system. Participants in this study were 443 students who used the OHS system type, and 408 who did not. All of them were enrolled in organic chemistry in 2010 or 2011 . The use of the system by learners for practising and studying improved their performance during the course, unlike students who practised only with problems from the textbook. Although the improvement in student performance was not statistically demonstrated, it was considered that the use of an

\footnotetext{
${ }^{4}$ Available in http://www2.saplinglearning.com
} 
OHS system offers an improved quality of education involving large groups. Offering individualised assistance to the average section size of 200 students during office hours is a challenge for any instructor. However, the aid of such systems allowed providing students with quick feedback as they study and practice.

The experience described by Ealy (2013) of a hybrid course in organic chemistry may be applicable to large groups as they could be divided, so that the teacher works with the two subgroups in separate sessions. This condition might improve the attention to students. The students met face-to-face for a 50 minutes, weekly class; the lectures were accessible online via Adobe Connect. The evaluation consisted of online tests through ANGEL, three tests in class and one final examination.

On the other hand, Schroeder and Greenbowe (2009) reported the use of Facebook in an introductory organic chemistry laboratory course with 128 students. The registration in Facebook was voluntary, 52 students participated and the tool functioned as an alternative for discussion of topics outside of class.

Wikis, collaborative Web pages that can be edited by different users, were utilised in a second-semester organic chemistry course. Students developed Web pages presenting mechanism of action of different molecules and received feedback from other students. The participants connected the course content to real-world applications and were exposed to different aspects of the scientific process: literature searching, construction and development of models, and peer review. The students reported the project made the course more relevant and even engaging and social. This in spite of facing difficulties with the technology for structure-drawing, threedimensional molecular view and interfaces for Web-based computational chemistry (Evans and Moore, 2011).

A Web-based tutorial program, ChemVoyage, was used in a third-year organic chemistry course. Each student entered the program using an avatar and a report card was available for self-assessment at any time, with information of all avatars and their scores. The authors of the program wanted to create a virtual sense of competition with the avatars and also anonymity to avoid discouragement in learning. The tutorial contained three levels and the student must complete all the questions correctly in a level to move to the next one (McRae, Karuso and Liu, 2012). 
Another example of the use of Web 2.0 tools in organic chemistry instruction is the use of cards or 'flashcards'. Pursell (2009), engaged students with cellulartelephone techniques. Although that article omits the number of participating students, the author mentioned that students reacted favourably to the technological tool; they found convenient the use of the cellular telephone, as they used this device every day. The author added, however, that the students could review the cards through their cellular telephone to study various topics of the course while those who lacked a suitable telephone could use their computers.

Draghici and Njardarson (2012) also reported the use of smart cards; they created an educational tool, which is freely accessible at http://chemistrybydesign.oia.arizona.edu. This site makes available several cards containing information on various organic reactions that serve to explore the knowledge in organic synthesis through tests. Furthermore, the same user can feed reactions to the educational site and has a possibility to use devices with Android or iOS operating systems.

There are many tools that use ICT to support knowledge construction and allow their use to facilitate learning through a collaborative space where students can interact. The goal of using technology is to support learning.

The questions guiding this study were:

(1) How the Web 2.0 tools are utilized by students and professors in courses?

(2) How effective is considered by the students the use of Web 2.0 tools in assisting learning of basic concepts in organic chemistry in Higher Education high enrolment courses?

\section{Methods}

The application of a mixed method seemed appropriate to carry out a research that answered the given questions. The study was quantitative in design, and a descriptive research methodology was used.

\subsection{Participants}

This study received approval according to the policies for conducting research with human subjects at the institution where it took place during the 2014 first semester. All participants received information detailing their rights as human subjects and knew they could 
withdraw from the study at any time. Informed consent was obtained from all participants. The research team member at the chemistry department in Costa Rica was the only one with access to participants' names and has online contact with the students to ensure confidentiality. This researcher was not in charge of any of the groups, which participated in this study. Participants in this quasi-experimental study were students from undergraduate organic courses at a large university in Costa Rica (more than 30000 students). In total the study included 537 students of age between 17 and 27 years (32\% male, $68 \%$ female), enrolled in a group of accelerated organic chemistry (four sections) and a group of general organic chemistry (two sections) and pursuing majors in health sciences, food science, natural sciences, agriculture, and engineering. No chemistry majors took part in this study. The recruitment occurred during the initial lecture in which the instructors explained the study protocol to the students. Only volunteers who completed all the assigned questionnaires and test were included in the analysis, resulting in a final sample of Cohort $1(N=92$, from a total of 355 students) that included the group of students who were enrolled in the conventional lectures, and Cohort 2 ( $\mathrm{N}=102$, from a total of 182 students) that included the students who also utilized Web 2.0 tools. Students in Cohort 1 and Cohort 2 came from 4 sections from the accelerated course and the 2 sections of the general course. Each section had its individual instructor. In total six instructors taught key concepts of organic chemistry (electronegativity, polar covalent bonding, steric effects, inductive effects, resonance and aromaticity) using traditional lecture methods. These themes were selected for this study because when such themes are understood, learning organic chemistry is greatly facilitated (Mullins, 2008). Sections of the accelerated organic course met twice in one week for a total of 150 minutes. Sections of the general organic course met three times over 1.5 weeks for a total of 150 minutes. The Web 2.0-enhanced sections utilized a blog constructed specifically for this research with entries on covered topics and videos selected from the open sources Khan Academy and YouTube. The videos were previously revised to ensure that the topics covered were adequate for the purposes of this study. The students were invited during the class periods to support their learning with their participation in the blog and videos. The students used the Web 2.0 tools during five weeks, since the key concepts were taught until the time of the examination where the concepts were evaluated. The students participated actively in the blog, sharing examples, asking questions about different examples they provided, and received feedback from other students and from the researcher in charge of the blog. 
All the professors from the Organic Chemistry Department, not only the Instructors of the selected sections were invited to respond to a questionnaire. The main objective of this survey was to learn about the use of Web 2.0 for personal, teaching or professional development purposes. Of 26 participants involved, 18 completed the survey (69\%). The instructor's ages were in a range 22-75 years, 8 females and 18 males.

\subsection{Instruments}

One test and three questionnaires were created for this study (Appendix 1-4). Test 1 included questions regarding knowledge of chemistry to assess student mastery of key concepts of chemistry from previous chemistry courses (diagnostic test). Questionnaire 1 involved questions to assess student knowledge of Web 2.0 tools, how they used the applications and their access to Internet and electronic devices. Questionnaire 2 included questions to discover whether the Web 2.0 tools were useful in student learning. Questionnaire 3 was similar to Questionnaire 2 but applied to instructors; its main objective was to assess use of Web 2.0 for personal, teaching or professional development purposes. Test 1 consisted mainly of multiple-choice items each with four options. Questionnaires 1, 2, and 3 used tick-box questions, limited option questions, and scale questions. The validity of the questionnaires and the test was confirmed through various collaborators. The test was reviewed by a group of chemistry professors and the questionnaires not only by the chemistry professors but also by educational technology professors to ensure that selected items were appropriate. A group of students also collaborated in ensuring clarity of the tasks. Based on feedback received, the instruments were refined. The test and questionnaires were applied online.

\subsection{Data collection and analysis}

The data were gathered from the test and questionnaires of students who attended class on a regular basis and who received instruction on the topics covered. Cohort 1 completed Questionnaire 1 while Cohort 2 completed Test 1 and Questionnaire 2. The students were asked to complete the corresponding surveys online through Google Docs. The instructors also received the survey online at the beginning of the study. The information regarding the impact of the use of Web 2.0 on student achievement was obtained from the grades that the students obtained from the examination in which the key concepts were 
evaluated. The instructors graded the examinations for their corresponding sections. The grades from all students were gathered and utilized for the analysis. The grades of Cohort 2 were utilized for comparison with the grades from the other groups. The obtained data were analyzed and tabulated in a suitable format in a spreadsheet using Microsoft Excel 2010. Student's t two-tailed test to a level of significance $\alpha=0.05$ was used to validate the difference between the medians of comparable groups. The Shapiro-Wilk test was used in combination with a Normal Probability Plot to check the normal distribution of the data. The homoscedasticity was checked using a standardized scatterplot and the Breusch-Pagan test.

\section{Results and Discussion}

\subsection{Use and knowledge of Web 2.0 within students}

The purpose of Questionnaire 1 was to discover the student's attitudes and actual uses of Web 2.0 tools, and any obstacles that can affect the adoption of the techniques such as lack of electronic devices or connection to the Internet. The obtained information is shown in Table 2.

Table 2. Characteristics of Cohort 1, students who complete Questionnaire 1.

\begin{tabular}{ll}
\hline Composition of Cohort 1 & 50 females, 42 males \\
\hline Internet access & Home (94\%), Internet Café (6 \%), Campus (100\%) \\
Equipment & Personal computer (83\%), smartphone (88\%), tablet (42\%) \\
Knowledge of Web 2.0 term & $21 \%$ \\
Uses of Web 2.0 tools & Socialize, news, create and share documents, music \\
Popular Web 2.0 tools & YouTube, Facebook, Dropbox, Drive, Twitter, Wikis, Blogs \\
Time per week using tools & $1-3$ hours (50\%) \\
\hline
\end{tabular}

Source: Researcher's own design (2018)

There was no difference between females and males in Cohort 1 regarding the use of Web 2. 0 tools and $90 \%$ of the population considered the tools easy to use. Web 2.0 was believed to be useful for the learning process, but $93 \%$ of the students disliked the idea of not having the traditional lecture, whereas $12 \%$ mentioned that they were happy with only the traditional lectures. According to the results, students were aware of the advantages of Web 2.0, but they felt uncomfortable using only Web 2.0 tools for learning. This reluctance seemed not due to technophobic attitudes, because the students have adopted the new technologies in their everyday life; it seemed to be related to internal and external contexts, to beliefs and 
attitudes that the students have about teaching and learning practices. An induction or training for the use of Web 2.0 was unnecessary for this population, but this factor must be taken into account before the use of these tools together with the access to the Internet. Internet penetration varies by country or even within a country. According to Straumann and Graham (2015), there is an "archipelago of disconnection", in which the center of the cluster contains 28 countries with penetration less than $10 \%$ of the threshold that they applied.

\subsection{Use of Web 2.0 by instructors}

The description of the personnel who participated in the survey and the information they gave are in table 3.

Table 3. Characteristics of instructors who participated in the study

\begin{tabular}{ll}
\hline Composition & 13 males, 5 females \\
\hline Internet access & Home (100\%), Campus (100\%) \\
Equipment & Personal computer and smartphone \\
Kwnoledge of Web 2.0 term & $33 \%$ \\
Uses of Web 2.0 tools & Collaboration and research dissemination, socialize, news, \\
& music and play \\
Popular Web 2.0 tools & YouTube, Facebook, Dropbox, Drive, Twitter, Wikis, Blogs, \\
& Podcast \\
Web 2.0 tools for teaching & Moodle, Dropbox, Wikis, YouTube, Blogs and Drive.
\end{tabular}

Source: Researcher's own design (2018)

All but one found Web 2.0 tools easy to use and all believed that the tools could support the learning process. However, only seven agreed with an online course and one considered only the traditional lectures to be appropriate as pedagogical approaches. Those seven instructors have utilized Web 2.0 tools only in groups with 30-40 students. From the 18 instructors who fulfilled the questionnaire 13 accepted the possibility of performing online examinations. All instructors used Internet, and Web 2.0 tools, in their daily life. It seems that Web 2.0 might be acceptable to support instruction in large groups. Research performed by Hartshorne and Ajjan (2009) showed that even though faculty members thought that Web 2.0 is effective in the classroom, few of them used the tools. The difference of our study from that of Hartshorne and Ajjan (2009) is that our instructors already utilized the applications even for teaching purposes. However, from our investigation it is unclear whether Web 2.0 tools were used to enable content sharing and collaborative learning. Technology must be an instrument to encourage students to communicate with one another to solve problems and to share 
knowledge, but this effect did not always happen. For example, in their study FeldmanMaggor, Rom and Tuvi-Arad (2016) found that teachers had integrated innovative learning materials, but they did not use Web 2.0 applications for sharing and collaborative learning. Even though our survey involves few participants, it seems that our group does not follow the tendencies described by Chiang, Huang and Huang (2009). According to those authors, males and younger participants were more frequent users of Internet whereas in this study we did no observe such differences in the use of Web 2.0. This difference might reflect a different level of schooling.

According to the result, a question arises: why instructors who are familiar and use Web 2.0 tools do not use them in their courses, especially those with many students? The reasons might be several, classifiable as personal, institutional and technical factors (Buabeng-Andoh 2012). In this investigation one factor might be lack of time, which is related to those three factors. It is not the same having 30 or 160 students in a classroom. At the institution where this study was carried out, time to prepare for class might have been insufficient because the time granted for preparation for a class with 10 students is the same as that for a class with 160.

\subsection{Opinion of students after the use of Web 2.0}

After the students utilized the blog and videos and after the examination was applied, they were invited to complete Questionnaire 2. In total 102 students (64 females and 38 males, $37 \%$ of the invited participants) completed the survey (Table 4).

Table 4. Students information regarding the use of Web 2.0 tools (Questionnaire 2)

\begin{tabular}{llll}
\hline Web 2.0 tool & Blog & Video & Observation \\
\hline Users & $86 \%$ & $77 \%$ & $\begin{array}{l}\text { The rest did not use it because they forgot or } \\
\text { did not have time }\end{array}$ \\
$\begin{array}{llll}\text { Easiness perception } \\
\begin{array}{l}\text { Perception of usefulness for } \\
\text { learning process }\end{array}\end{array}$ & $86 \%$ & $74 \%$ & $\begin{array}{l}\text { Only 3\% considered difficult to use the tools. } \\
91 \% \text { of students considered Moodle also } \\
\text { useful. }\end{array}$ \\
\hline
\end{tabular}

Source: Resesarcher's own design (2018)

The survey also invited students to comment on any other aspect they considered important. The most recurrent comment was that the blog and the videos were useful and that it was important to embed a link to them in Moodle and to continue their use in future courses. They also asked for videos in the language of instruction (Spanish), and for further 
information regarding advanced organic chemistry, open online courses from MIT or Harvard, and the use of EdX or Coursera. A single comment that was made and that drew attention was that social networks should not be used in education. According to the information obtained, the perception of most students was that Web 2.0 tools were useful to support their studies. This finding is consistent with the report of Kumar (2009); in a study of undergraduate students from various disciplines he found that respondents felt that blogs and videos were among the most useful applications for education at university level. Waycott et al. (2010) mentioned that undergraduates identified various benefits of using technology: communication benefits, convenience, access to information and enabled flexible use of resources. It is, however, possible to find in the literature contrary observations, such as those of Collis and Moonen (2008): there are inconsistencies in the perceptions of the quality of the education that is offered with the tools.

\subsection{Students performances after applying Web 2.0 tools for supporting learning}

The acquired knowledge was assessed with examinations provided by the instructors. The accelerated organic chemistry instructors applied one exam and the general organic chemistry instructors another. These examinations contained mainly short answer questions and few matching questions to test student knowledge. The grades of the students who utilized the Web 2.0 tools, in total 102 students (Cohort 2), were compared with the qualifications obtained by those who did not support their knowledge with those applications - Sections 1, 2, 3 and 6. The mean, median, standard deviation and variance of the total scores obtained by students were calculated. The values of mean and median were similar; where greater difference occurred was in Section 2; we assumed that the data distribution was fairly symmetric in each section. Standard deviations and variances certainly showed that there was a greater dispersion of data in Section 2 and less in Section 3. The reasons for the dispersions within each section and between sections might be many, especially when one considers that those values represent individuals who differ in their abilities and life experiences (Table 5). According to the medians, students from Cohort 2 achieved a better performance than students in other sections, who did not utilize Web 2.0 tools. 
Table 5. Comparison of grades between Cohort 2 and traditional sections

\begin{tabular}{llllll}
\hline Population & $\mathrm{N}$ & Median & Mean & SD & Variance \\
\hline Cohort 2 $^{\mathrm{a}}$ & 101 & 66 & 65.5 & 14.07 & 198.07 \\
Section $^{\mathrm{b}}$ & 95 & 59.7 & 60 & 13.39 & 179.22 \\
Section 2 $^{\mathrm{b}}$ & 91 & 52.2 & 54.5 & 17.14 & 293.7 \\
Section 3 $^{\mathrm{c}}$ & 74 & 66.9 & 67.1 & 13.17 & 173.54 \\
Section $^{\mathrm{b}}$ & 95 & 58.1 & 58.2 & 14.6 & 213.06 \\
\hline
\end{tabular}

aStudents who used Web 2.0 tools/ ${ }^{b}$ Accelerated organic chemistry/ ${ }^{c}$ General organic chemistry. Source: Resesarcher's own design (2018)

An independent Student's t test was used to validate statistically the differences observed in the medians and to compare performance. According to the statistical treatment, there was a significant difference between the academic performance of Cohort 2 students $(M=66.0, S D=14.07)$ and those in sections $1(M=59.7, S D=13.39), 2(M=52.2, S D=17.14)$ and $6(M=58.1, S D=14.60)$ under the conditions $t(186)=-3.294, p=0.002, t(174)=-5.758$, $\mathrm{p}<0.001, \mathrm{t}(182)=-3.6, \mathrm{p}<0.001$, respectively, but there was no difference in the academic performance between Cohort $2(M=66.0, S D=14.07)$ and Section $3(M=66.9, S D=13.17)$ under the conditions $\mathrm{t}(164)=0.476, \mathrm{p}=0.635$. The Student's $\mathrm{t}$ test results confirmed that the performance of the students from Cohort 2 was better than all sections with the exception of Section 3. The difference between Section 3 and Sections 1, 2 and 6 was that the first one corresponds to the general organic chemistry course and the others to the accelerated organic chemistry course. The time invested in class for covering the key concepts in the general and the accelerated courses was the same, according to the syllabus of the courses and the information given by the different instructors. On the other hand, the cumulative grade-point averages for the sections were different, and Section 3 has the lowest cumulative grade point average (Table 6). The applied exams and the topics evaluated were also different for the accelerated and the general organic chemistry course: the first one covers more topics in the examination. A better performance of students in the general organic course might be favored with this situation. Students from accelerated courses might feel time constraints in completion of the topics to be covered for the examination: this distress was not necessarily present in the general course. 
Table 6. Cumulative grade-point averages of Cohort 2 and traditional sections

\begin{tabular}{|c|c|c|c|c|}
\hline \multirow{2}{*}{ Cohort $2^{a}$} & \multicolumn{4}{|c|}{ Sections } \\
\hline & $1^{\mathrm{b}}$ & $2^{b}$ & $3^{c}$ & $6^{a}$ \\
\hline 78.9 & 81.2 & 77.9 & 55.0 & 79.8 \\
\hline
\end{tabular}

A qualitative comparison was also made between the performance of students of Cohort 2 in the diagnostic test (Appendix 5) and in the examinations applied by the instructors after the intervention (Table 7). According to the data, there was an improvement in the students after they utilized the tools. A dependent Student's $t$ test was applied: the grades obtained in the diagnostic test $(M=38.0, S D=16.89)$, and those obtained in the exams ( $M=$ $61.0, \mathrm{SD}=13.63$ ) are statistically different under the condition $\mathrm{t}(8)=1.766, \mathrm{p}=0.03$.

Table 7. Comparison of the academic performance of students from Cohort 2 in the diagnostic test and in the examination that used Web 2.0 tools to support learning

\begin{tabular}{lcc}
\multicolumn{1}{c}{ Themes } & $\begin{array}{c}\text { Diagnostic Test/\% } \\
\text { (before intervention) }\end{array}$ & $\begin{array}{c}\text { Examination } / \% \\
\text { (after intervention) }\end{array}$ \\
\hline Lewis structures & 21 & 72 \\
Hibridization/geometry & 63 & 88 \\
Intermolecular forces & 32 & 61 \\
Solubility & 54 & 56 \\
Acidity and basicity & 8 & 56 \\
\hline
\end{tabular}

Source: Researcher's own design (2018)

\section{Conclusions}

Most students in this study own a computer and smartphone and had access to Internet from home or an Internet cafe nearby. They also connected to Internet via Wi Fi or in the various computer rooms on campus. All used Web 2.0 tools for recreational purposes, to socialize, to follow the news and celebrities, to create and to share documents, to listen to music, so they were accustomed to YouTube, Facebook, Dropbox, Google Docs, Twitter, wikis and blogs, among other applications. The situation with the instructors was similar: they had access to Internet and used applications for their professional and personal lives.

The participants in this research believed that the tools were useful for the teachinglearning process. The undergraduates considered that the applications assisted their studies and most thought that they were easy to use. The instructors acknowledged that Web 2.0 
could contribute to support the educational process, but they had not used them in large groups.

According to this investigation, the blog and videos had a positive impact on the student's academic performance in most sections included in this study, according to the analysis of Student's t test at a significance level $p=0.05$. These results were in alignment with educational research findings and showed a positive scenario for the application of Web 2.0 tools in support of teaching and learning of organic chemistry in large enrolment groups. As mentioned by Hartshorne and Ajjan (2009), the perception of usefulness, ease of use and compatibility have an effect on a positive attitude toward the use of the techniques, but the introduction of Web 2.0 practice into learning activities might create challenges in practice and must be considered in a student-centered process of a learning-teaching environment, the workload of the instructors and an institutional decision and support to apply the techniques.

\section{Acknowledgments}

This work was supported in part by Costa Rica United States Foundation for Cooperation (CRUSA) and Tecnológico de Monterrey. We also thank Santiago Ureña and John Ogilvie for comments that helped to make this a better paper.

\section{References}

Alvarez-Flores, Erika and Nuñez, Patricia. (2013). Uso de redes sociales como elemento de interacción y construcción de contenidos en el aula: cultura participativa a través de Facebook. Historia y Comunicación Social, 18, 53-62.

Arasasingham, Ramesh, Taagepera, Mare, Potter, Frank, Martorell, Ingrid and Lonjers, Stacy. (2005). Assessing the effect of Web-based learning tools on student understanding of stoichiometry using knowledge space theory. Journal of Chemical Education, 82(8), 1251-1262.

Bennett, Sue, Bishop, Andrea, Dalgarno, Barney, Waycott, Jenny and Kennedy, Gregor. (2012). Implementing Web 2.0 technologies in higher education: A collective case study. Computers and Education, 59(2), 524-534. Doi https://doi.org/10.1016/j.compedu.2011.12.022

Buabeng-Andoh, Charles. (2012). Factors influencing teachers' adoption and integration of information and communication technology into teaching: A review of the literature. International Journal of Education and Development using Information and Communication Technology, 8(1), 136-155. 
Bunce, Diane M., VandenPlas, Jessica, R. and Havanki, Katherine L. (2006). Comparing the effectiveness on student achievement of a student response system versus online WebCT quizzes. Journal of Chemical Education, 83(3), 488-493.

Chiang, I-Ping, Huang, Chun-Yao and Huang, Chen-Wen. (2009). Characterizing Web users' degree of Web 2.0-ness. Journal of the American Society for Information Science and Technology, 60(7), 1349-1357.

Chickering, Arthur W. and Gamson, Zelda F. (1987). Seven Principles for Good Practice in Undergraduate Education. American Association for Higher Education Bulletin, 39, 3-7.

Collis, Betty and Moonen, Jef. (2008). Web 2.0 tools and processes in higher education: quality perspectives. Educational Media International, 45(2), 93-106.

Dalgarno, Barney, Bishop, Andrea G., Adlong, William and Bedgood, Danny R. Jr. (2009). Effectiveness of a virtual laboratory as a preparatory resource for distance education chemistry students. Computers and Education, 53(3), 853-865. Doi https://doi.org/10.1016/i.compedu.2009.05.005

Davis, Carrie and Goodman, Harriet. (2014). Virtual communities of practice in social group work education. Social Work with Groups, 37(1), 85-95.

Bonderup, Nina. (2009). Web 2.0: Inherent tensions and evident challenges for education. International Journal of Computer-Supported Collaborative Learning, 4(3), 343-363.

Draghici, Cristian and Njardarson, Jon T. (2012). Chemistry by design: a web-based educational flashcard for exploring synthetic organic chemistry. Journal of Chemical Education, 89(8), 1080-1082.

Dunlap, Joanna C. and Lowenthal, Patrick R. (2018). Online educators' recommendations for teaching online: Crowdsourcing in action. Open Praxis, 10(1), 79-89.

Ealy, Julie B. (2013). Development and implementation of a first-semester hybrid organic chemistry course: yielding advantages for educators and students. Journal of Chemical Education, 90(3), 303-307.

Evans, Michael J. and Moore, Jeffrey S. (2011). A collaborative, Wiki-based organic chemistry project incorporating free chemistry software on the Web. Journal of Chemical Education, 88(6), 764-768.

Feldman-Maggor, Yael, Rom, Amira and Tuvi-Arad, Inbal. (2016). Integration of open educational resources in undergraduate chemistry teaching - a mapping tool and lecturers' considerations. Chemistry Education Research and Practice, 17(2), 283-295.

Goodfellow, Geoffrey W. and Maino, Dominick M. (2010). ASCOTech: World Wide Web as easy as 1.0, 2.0, 3.0. Optometric Education, 35(2), 62-63. 
Grosseck, Gabriela (2009). To use or not to use Web 2.0 in Higher Education? Procedia Social and Behavioral Sciences, 1(1), 478-482

Hartshorne, Richard and Ajjan, Haya. (2009). Examining student decisions to adopt Web 2.0 technologies: theory and empirical tests. Journal of Computing in Higher Education, 21(3), 183-198.

Johnson, Sherryl. (2014). Applying the seven principles of good practices: technology as a lever -in an online research course. Journal of Interactive Online Learning, 13(2), 41-50.

Kose, Utku. (2015). On the state of free and open source e-learning 2.0 software. International Journal of Open Source Software Processes, 5(2), 55-75.

Kumar, Swapna. (2009). Undergraduate perceptions of the usefulness of Web 2.0 in higher education: Survey development. Proceedings of the European Conference on eLearning. 29-30 Octuber. Retrevied http://books.google.com/books?hl=en\&lr=\&id=qGw4tvVrKUEC\&oi=fnd\&pg=PA308\&dq= Undergraduate+Perceptions+of+the+Usefulness+of+Web+2+0+in+Higher+Education+ Survey+Development\&ots=ra43C4uUvg\&sig=iAZKC MEzH3g1HU7OIKe8vufaNI

Lenert, Kathleen A. and Janes, Dianne P. (2017). The incorporation of quality attributes into online course design in Higher Education. International Journal of E-Learning and Distance Education, 32(1), 1-14.

McRae Christopher, Karuso Peter and Liu Fei. (2012). ChemVoyage: a Web-based, simulated learning environment with scaffolding and linking visualization to conceptualization. Journal of Chemical Education, 89(7), 878-883.

Mullins, Joseph J. (2008). Six Pillars of Organic Chemistry. Journal of Chemical Education, 85(1), 83-87.

Parker Laurie L. and Loudon G. Marc. (2013). Case study using online homework in undergraduate organic chemistry: results and student attitudes. Journal of Chemical Education, 90(1), 37-44.

Pursell, David P. (2009). Adapting to student learning styles: Engaging students with cell phone technology in organic chemistry instruction. Journal of Chemical Education, 86(10), 1219-1222.

Schroeder Jacob and Greenbowe Thomas J. (2009). The chemistry of Facebook: using social networking to create an online community for the organic chemistry laboratory. Innovative: Journal of Online Education, 5(4). Retrieved from http://nsuworks.nova.edu/innovate/vol5/iss4/3.

Shultz, Ginger V., Winschel, Grace A., Inglehart, Ronald C. and Coppola, Brian P. (2014). Eliciting student explanations of experimental results using an online discussion board. Journal of Chemical Education, 91(5), 684-686. 
Straumann, Ralph K. and Graham, Mark. (2015). Who isn't online? Mapping the 'Archipelago of Disconnection'. Regional Studies, Regional Science, 3(1), 96-98.

Tess, Paul A. (2013). The role of social media in higher education classes (real and virtual) A literature review. Computers in Human Behavior, 29(5), A60-A68.

Centre for Learning \& Performance Technologies. (2017). Top 200 tools for learning, 2017. Retrieved from https://es.slideshare.net/janehart/top-100-tools-for-learning$\underline{2017}$

Ulrich, Jana and Karvonen, Meagan. (2011). Faculty instructional attitudes, interest, and intention: Predictors of Web 2.0 use in online courses. Internet and Higher Education, 14(4), 207-216.

Waycott Jenny, Bennett Sue, Kennedy Gregor and Dalgarno Barney. (2010). Digital divides? Student and staff perceptions of information and communication technologies. Computers and Education, 54(4), 1202-1211.

Waycott Jenny, Bennett Sue, Kennedy, Gregor Dargarno, Barney and Gray Kathleen. (2010), Digital divides? Student and staff perceptions of information and communication technologies. Computers and Education, 54(4), 1202-1211.

Waycott, Jenny and Kennedy, Gregor. (2009). Mobile and Web 2.0 technologies in undergraduate science: Situating learning in everyday experience. In Same places, different spaces. Proceedings ascilite Auckland 2009. 6-9 December. Retrieved http://www.ascilite.org.au/conferences/auckland09/procs/waycott.pdf

Woodfield, Brian F., Andrus, Merritt B., Andersen, Tricia, Miller, Jordan, Simmons, Bryon, Stanger, Richard, Waddoups, Gregory L., Moore, Melissa S., Swan, Richard A., Allen, Rob and Bodily, Greg. (2005). The Virtual ChemLab proyect: a realistic and sophisticated simulation of organic synthesis and organic qualitative analysis. Journal of Chemical Education, 82(11), 1728-1735.

Woodfield, Brian F., Catlin, Heidy R., Waddoups, Gregory L., Moore, Melissa S., Swan, Richard A., Allen, Rob and Bodily, Greg. (2004). The Virtual ChemLab proyect: a realistic and sophisticated simulation of inorganic qualitative analysis. Journal of Chemical Education, 81(11), 1672-1678. 
APPENDIX 1: online questionnaire "Knowledge and use of Web 2.0 tools by instructors"

This survey is anonymous and aims to know your opinion about the Web 2.0 tools and their use in teaching.

1. Academic degree:

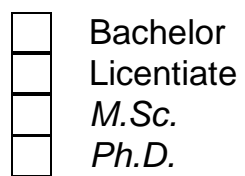

2. Time served: (years, months)

3. Sex:<smiles>CCCCCCCC1CCC1CCCC</smiles>

4. According to your knowledge, which is a definition for Web 2.0 ?

I have never heard the term I have heard the term but I do not know its meaning Set of technologies, services and tools to collaborate and participate in the creation of content, knowledge generation and sharing information online.

Set of programs used on the Internet 2.0, which is part of a consortium that develops applications and technologies for transferring information to a high speed.

$\square$ Set of tools, which uses the Internet 2.0 technology and are used by academic, industrial and governmental institutions worldwide.

5. How do you access Internet? You can choose several options.

$\square$ I connect at home

I connect at the University

I use $3 G$ or $4 G$ from the cell phone providers

I I use free Wi Fi at different places

Other:

6. Which type of electronic device you use to connect to the Internet? You can choose several options.

I use a desktop at the University

I use a desktop at home

I use my portable computer

I use my own tablet

I use a cell phone

Other:

7. Please rate your satisfaction regarding the Internet connection you use. 


\begin{tabular}{lccccc} 
& $\begin{array}{c}\text { Very } \\
\text { satisfied }\end{array}$ & $\begin{array}{c}\text { Somewhat } \\
\text { satisfied }\end{array}$ & $\begin{array}{c}\text { Neither satisfied } \\
\text { nor dissatisfied }\end{array}$ & $\begin{array}{c}\text { Somewhat } \\
\text { dissatisfied }\end{array}$ & $\begin{array}{c}\text { Very } \\
\text { dissatisfied }\end{array}$ \\
\hline $\begin{array}{l}\text { University } \\
\text { Connection }\end{array}$ & 0 & 0 & 0 & 0 & 0 \\
\hline University Wi Fi & 0 & 0 & 0 & 0 & 0 \\
\hline Home connection & 0 & 0 & 0 & 0 & 0 \\
\hline Free Wi Fi & 0 & 0 & 0 & 0 & 0 \\
\hline 3G/4G service & 0 & 0 & 0 & 0 & 0 \\
\hline
\end{tabular}

8. Which applications you use in your daily life? You can choose several options.

\begin{tabular}{|l|l|l|l}
$\begin{array}{l}\text { Facebook } \\
\text { Blogs } \\
\text { Wikis }\end{array}$ & $\begin{array}{l}\text { GoogleDocs } \\
\text { Podcasts } \\
\text { Twitter }\end{array}$ & $\begin{array}{l}\text { YouTube } \\
\text { Dropbox } \\
\text { Other: }\end{array}$ \\
\hline
\end{tabular}

9. For what do you use the apps? You can choose several options.

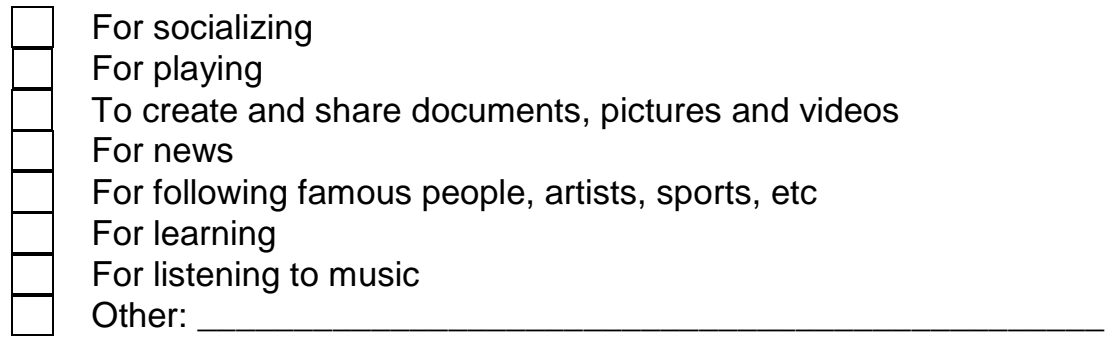

10. How many hours per week you spend using the apps?

\begin{tabular}{|c|c|c|c|c|c|c|}
\hline & 0 & $1-3$ & $3-6$ & $6-9$ & 9-12 & $\geq 12$ \\
\hline Facebook & $\mathrm{O}$ & $\mathrm{o}$ & $\mathrm{O}$ & $\mathrm{O}$ & $\mathrm{O}$ & $\mathrm{O}$ \\
\hline Twitter & $\mathrm{O}$ & $\mathrm{O}$ & $\mathrm{O}$ & $\mathrm{O}$ & $\mathrm{O}$ & $\mathrm{O}$ \\
\hline YouTube & $\mathrm{O}$ & $\mathrm{O}$ & $\mathrm{O}$ & $\mathrm{O}$ & $\mathrm{O}$ & $\mathrm{O}$ \\
\hline Blogs & $\mathrm{O}$ & o & o & $\mathrm{O}$ & $\mathrm{O}$ & $\mathrm{O}$ \\
\hline Wikis & $\mathrm{O}$ & $\mathrm{O}$ & $\mathrm{O}$ & $\mathrm{O}$ & $\mathrm{O}$ & $\mathrm{O}$ \\
\hline GoogleDocs & $\mathrm{O}$ & $\mathrm{O}$ & $\mathrm{O}$ & $\mathrm{O}$ & $\mathrm{O}$ & $\mathrm{O}$ \\
\hline Podcast & $\mathrm{O}$ & $\mathrm{O}$ & $\mathrm{O}$ & $\mathrm{O}$ & $\mathrm{O}$ & $\mathrm{O}$ \\
\hline Dropbox & $\mathrm{O}$ & $\mathrm{O}$ & $\mathrm{O}$ & $\mathrm{O}$ & $\mathrm{O}$ & $\mathrm{O}$ \\
\hline
\end{tabular}


11. How easy to use are the technologies for you?

\begin{tabular}{|c|c|c|c|c|c|}
\hline & Very easy & Easy & Difficult & $\begin{array}{c}\text { Very } \\
\text { Difficult }\end{array}$ & $\begin{array}{l}\text { I have not } \\
\text { use them }\end{array}$ \\
\hline Facebook & $\mathrm{O}$ & $\mathrm{O}$ & $\mathrm{O}$ & $\mathrm{O}$ & $\mathrm{O}$ \\
\hline Twitter & $\mathrm{O}$ & $\mathrm{o}$ & $\mathrm{O}$ & $\mathrm{O}$ & $\mathrm{O}$ \\
\hline YouTube & $\mathrm{O}$ & $\mathrm{o}$ & $\mathrm{O}$ & o & $\mathrm{O}$ \\
\hline Blogs & $\mathrm{O}$ & $\mathrm{o}$ & $\mathrm{O}$ & $\mathrm{o}$ & $\mathrm{O}$ \\
\hline Wikis & $\mathrm{O}$ & $\mathrm{O}$ & $\mathrm{O}$ & o & $\mathrm{O}$ \\
\hline GoogleDocs & $\mathrm{O}$ & $\mathrm{O}$ & $\mathrm{O}$ & $\mathrm{O}$ & $\mathrm{O}$ \\
\hline Podcast & $\mathrm{O}$ & $\mathrm{O}$ & $\mathrm{O}$ & $\mathrm{O}$ & $\mathrm{O}$ \\
\hline Dropbox & $\mathrm{O}$ & $\mathrm{O}$ & $\mathrm{O}$ & $\mathrm{O}$ & $\mathrm{O}$ \\
\hline
\end{tabular}

12. Have you used any of the former enlisted apps in your classes?
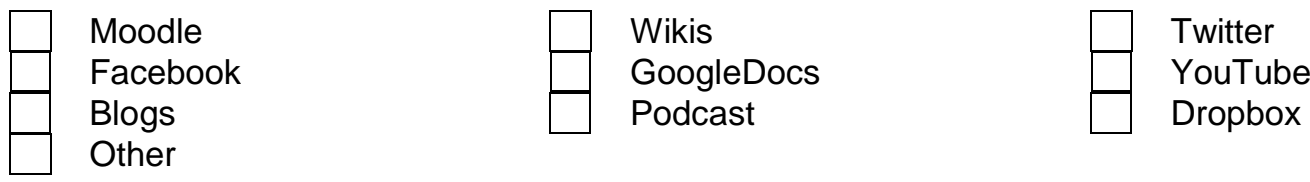

13. Do you think that the apps are useful for the teaching-learning process?

Yes, I have utilized them in courses and are useful Yes, however I have not used them in my lectures No, I have used them but they are not.

No, I have not used them however I think there are not useful

14. Would you be willing to use Web 2.0 tools for teaching in Organic Chemistry courses in a way that the instructor only provides consultancy hour?

$\square$ Yes, I think it is a good idea

Yes, however I think the traditional lecture should always be given

No, I think the traditional lecture must be given

Other:

15. Would you be willing to apply quizzes and examinations via online?

\begin{tabular}{|l}
$\square \quad \begin{array}{l}\text { Yes } \\
\text { No } \\
\text { Other: }\end{array}$ \\
\end{tabular} 


\section{APPENDIX 2: online questionnaire "Knowledge and use of Web 2.0 tools by students"}

This survey is anonymous and aims to know your opinion about the Web 2.0 tools and their use in teaching.

1. Organic course you are attending:

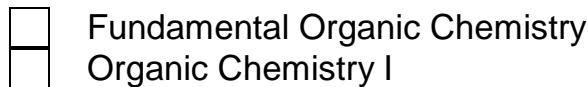

2. Which professional career are you studying?

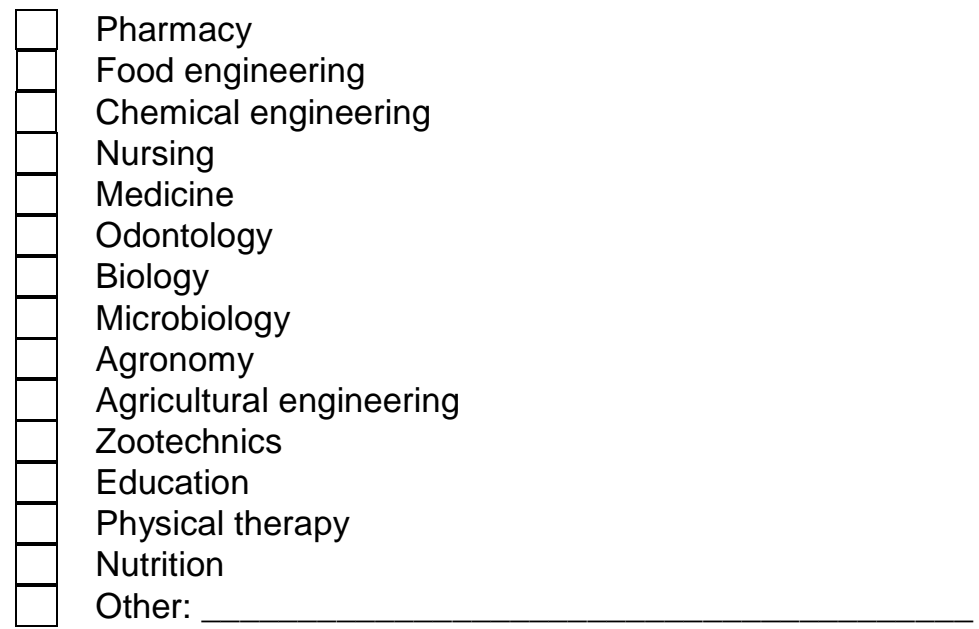

4. Age: (years)

5. Sex: Female
Male

6. According to your knowledge, which is a definition for Web 2.0?

I have never heard the term

I have heard the term but I do not know its meaning

Set of technologies, services and tools to collaborate and participate in the creation of content, knowledge generation and sharing information online.

Set of programs used on the Internet 2.0, which is part of a consortium that develops applications and technologies for transferring information to a high speed.

Set of tools, which uses the Internet 2.0 technology and are used by academic, industrial and governmental institutions worldwide.

7. How do you access Internet? You can choose several options.

I connect at home

I connect at the University

I use $3 G$ or $4 G$ from the cell phone providers

I use free Wi Fi at different places

Other: 
8. Which type of electronic device you use to connect to the Internet? You can choose several options.

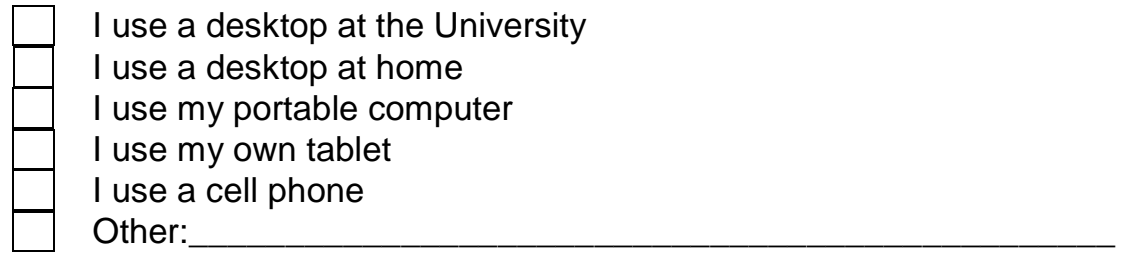

9. Please rate your satisfaction regarding the Internet connection you use.

\begin{tabular}{lccccc} 
& $\begin{array}{c}\text { Very } \\
\text { satisfied }\end{array}$ & $\begin{array}{c}\text { Somewhat } \\
\text { satisfied }\end{array}$ & $\begin{array}{c}\text { Neither } \\
\text { satisfied nor } \\
\text { dissatisfied }\end{array}$ & $\begin{array}{c}\text { Somewhat } \\
\text { dissatisfied }\end{array}$ & $\begin{array}{c}\text { Very } \\
\text { dissatisfied }\end{array}$ \\
\hline $\begin{array}{l}\text { University } \\
\text { Connection }\end{array}$ & $\mathrm{o}$ & $\mathrm{o}$ & $\mathrm{o}$ & $\mathrm{o}$ & $\mathrm{O}$ \\
\hline University Wi Fi & $\mathrm{O}$ & $\mathrm{O}$ & $\mathrm{O}$ & $\mathrm{O}$ & $\mathrm{O}$ \\
\hline Home connection & $\mathrm{O}$ & $\mathrm{O}$ & $\mathrm{O}$ & $\mathrm{O}$ & $\mathrm{O}$ \\
\hline Free Wi Fi & $\mathrm{O}$ & $\mathrm{O}$ & $\mathrm{O}$ & $\mathrm{O}$ & $\mathrm{O}$ \\
\hline 3G/4G service & $\mathrm{O}$ & $\mathrm{O}$ & $\mathrm{O}$ & $\mathrm{O}$ & $\mathrm{O}$ \\
\hline
\end{tabular}

10. Which applications you use in your daily life? You can choose several options.
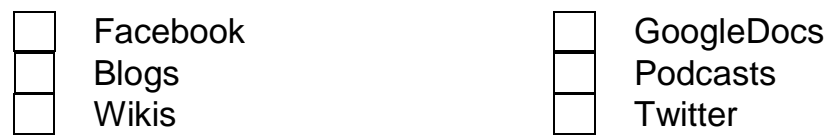

YouTube
Dropbox
Other:

11. For what do you use the apps? You can choose several options.

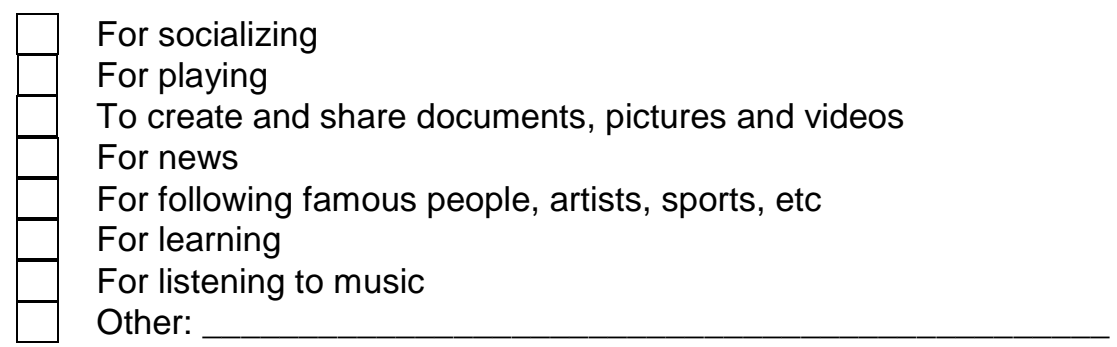

12. How many hours per week you spend using the apps?

\begin{tabular}{|c|c|c|c|c|c|c|}
\hline & 0 & $1-3$ & $3-6$ & $6-9$ & $9-12$ & $\geq 12$ \\
\hline Facebook & $\mathrm{O}$ & $\mathrm{O}$ & $\mathrm{O}$ & $\mathrm{O}$ & $\mathrm{O}$ & $\mathrm{O}$ \\
\hline Twitter & $\mathrm{O}$ & $\mathrm{O}$ & $\mathrm{O}$ & $\mathrm{O}$ & $\mathrm{O}$ & $\mathrm{O}$ \\
\hline YouTube & $\mathrm{O}$ & $\mathrm{O}$ & $\mathrm{O}$ & $\mathrm{O}$ & $\mathrm{O}$ & $\mathrm{O}$ \\
\hline Blogs & $\mathrm{O}$ & $\mathrm{O}$ & $\mathrm{O}$ & $\mathrm{O}$ & $\mathrm{O}$ & $\mathrm{O}$ \\
\hline Wikis & $\mathrm{O}$ & $\mathrm{O}$ & $\mathrm{O}$ & $\mathrm{O}$ & $\mathrm{O}$ & $\mathrm{O}$ \\
\hline GoogleDocs & $\mathrm{O}$ & $\mathrm{O}$ & $\mathrm{O}$ & $\mathrm{O}$ & $\mathrm{O}$ & $\mathrm{O}$ \\
\hline Podcast & $\mathrm{O}$ & $\mathrm{O}$ & $\mathrm{O}$ & $\mathrm{O}$ & $\mathrm{O}$ & $\mathrm{O}$ \\
\hline Dropbox & $\mathrm{O}$ & $\mathrm{O}$ & $\mathrm{O}$ & $\mathrm{O}$ & $\mathrm{O}$ & $\mathrm{O}$ \\
\hline
\end{tabular}


13. How easy to use are the technologies for you?

\begin{tabular}{|c|c|c|c|c|c|}
\hline & Very easy & Easy & Difficult & $\begin{array}{c}\text { Very } \\
\text { Difficult }\end{array}$ & $\begin{array}{l}\text { I have not } \\
\text { use them }\end{array}$ \\
\hline Facebook & $\mathrm{O}$ & $\mathrm{O}$ & $\mathrm{o}$ & $\mathrm{O}$ & $\mathrm{O}$ \\
\hline Twitter & $\mathrm{O}$ & $\mathrm{O}$ & $\mathrm{o}$ & $\mathrm{O}$ & $\mathrm{O}$ \\
\hline YouTube & $\mathrm{O}$ & $\mathrm{O}$ & $\mathrm{O}$ & $\mathrm{O}$ & $\mathrm{o}$ \\
\hline Blogs & $\mathrm{o}$ & $\mathrm{O}$ & $\mathrm{O}$ & $\mathrm{O}$ & $\mathrm{O}$ \\
\hline Wikis & $\mathrm{O}$ & $\mathrm{o}$ & $\mathrm{O}$ & $\mathrm{O}$ & $\mathrm{O}$ \\
\hline GoogleDocs & $\mathrm{O}$ & $\mathrm{O}$ & $\mathrm{O}$ & $\mathrm{O}$ & $\mathrm{O}$ \\
\hline Podcast & $\mathrm{O}$ & $\mathrm{O}$ & $\mathrm{O}$ & $\mathrm{O}$ & $\mathrm{O}$ \\
\hline Dropbox & $\mathrm{O}$ & $\mathrm{O}$ & $\mathrm{O}$ & $\mathrm{O}$ & $\mathrm{O}$ \\
\hline
\end{tabular}

14. Have you used any of the former enlisted apps in the courses at the University? You can choose several options.

Facebook

Blogs

Wikis

\begin{tabular}{|l}
$\square$ \\
$\square$ \\
$\begin{array}{l}\text { GoogleDocs } \\
\text { Podcasts } \\
\text { Twitter }\end{array}$
\end{tabular}

Twitter

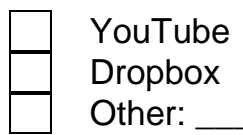

Other:

15. Do you think that the apps are support your learning process?

Yes, I have utilized them in courses and are useful

Yes, however I have not used them

No, I have used them but they are not

No, I don't think there are useful

16. Would you be willing to use Web 2.0 tools in Organic Chemistry courses in a way that the instructor only provides consultancy hour?

Yes, I think it is a good idea

Yes, however I think the traditional lecture should always be given

No, I think the traditional lecture must be given

Other:

17. Would you be willing to have quizzes and examinations via online?

\begin{tabular}{|l|l}
$\square$ & Yes \\
& No \\
& Other:
\end{tabular}

\section{APPENDIX 3: online questionnaire "Diagnostic questionnaire of previous knowledge in Chemistry"}

This survey is anonymous and aims to know your previous knowledge in Chemistry.

1. According to your knowledge, which atoms are isotopes?
a. ${ }^{12} \mathrm{C}$ and ${ }^{13} \mathrm{C}$
b. Hydrogen, deuterium and tritium
c. Atoms in both items a. and b. are isotopes
d. None of the above 
2. The number of bonds an atom usually forms is called "valence". The valence of carbon, nitrogen and oxygen is:
a. 6,7 and 8
b. 2, 3 and 4
c. 4,5 and 6
d. None of the above

3. Which compound has a covalent bonding:
a. $\mathrm{LiF}$
b. $\mathrm{NaCl}$
c. $\mathrm{CCl}_{4}$
d. None of the above

4. The electronic configuration of carbon is:
a. $1 s^{2} 2 s^{2} 2 p^{3}$
b. $1 s^{2} 2 s^{2} 2 p^{4}$
c. $1 s^{2} 2 s^{2} 2 p^{1}$
d. None of the above

5. Choose the correct Lewis structure of nitric acid:

\begin{tabular}{|c|c|c|c|}
\hline 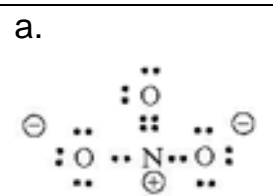 & $\begin{array}{l}\text { b. } \\
\quad: \ddot{O}: \ddot{\mathrm{O}}: . . \mathrm{O}: \\
\quad . .\end{array}$ & 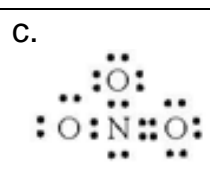 & d. None \\
\hline
\end{tabular}

6. What is an isomer?
a. An element with a different number of neutrons
b. Molecules with different physical properties
c. Molecules with the same molecular formula but different structure
d. Molecules with the same shape and size

7. Which is the strongest acid?
a. $\mathrm{HF}$
b. $\mathrm{HCl}$
c. $\mathrm{HBr}$
d. $\mathrm{H}_{2} \mathrm{~S}$

8. Classify each compound, molecule or mixture according to: neutral $(\mathrm{N})$, acidic $(\mathrm{Ac})$, alkaline $(\mathrm{Al})$, oxidizing agent $(\mathrm{OA})$ or reducing agent (RA):
( ) Sodium bicarbonate
( ) Commercial chlorine
( ) liquor
( ) Zinc sheets
( ) Orange juice
( ) Vinegar

9. If you have pure water at $0^{\circ} \mathrm{C}$, and you warm it and measure the $\mathrm{pH}$ at different temperatures, what do you expect?: 
a. The $\mathrm{pH}$ increases when the temperature is increased

b. The $\mathrm{pH}$ decreases when the temperature is increased

c. The temperature does not affect the $\mathrm{pH}$

d. None of the above

10. From the following molecules, choose:<smiles>CCC</smiles><smiles>CC(=O)O</smiles>

5<smiles>COC</smiles>

2<smiles>CC(C)=O</smiles>

6<smiles>CC=O</smiles>

3<smiles>S</smiles>

7<smiles>CN</smiles>

4<smiles>CO</smiles>

8
a. Two molecules whose bigger interaction force is dipole-dipole:
b. Two molecules which can form hydrogen bond:
c. Two molecules which are soluble in water:
d. Two molecules which are soluble in hexane:

11. Which is the geometry of the molecule $\mathrm{H}_{3} \mathrm{C}-\mathrm{S}(=\mathrm{O}) \mathrm{CH}_{3}$ around the sulphur atom?
a. Linear geometry
b. Trigonal geometry
c. Tetrahedral geometry
d. Octahedral geometry
e. None of the above

12. Which compound has the atom with the higher oxidation state?:
a. Hydrocarbon
b. Alcohol
c. Water
d. Carboxilic acid

13. The correct order of electronegativity is:
a. $\mathrm{H}>\mathrm{He}>\mathrm{Li}>\mathrm{Be}$
b. $\mathrm{F}>\mathrm{O}>\mathrm{N}>\mathrm{C}$
c. $\mathrm{Ce}^{+}>\mathrm{Ce}^{+2}>\mathrm{Ce}^{+3}>\mathrm{Ce}^{+4}$
d. $\mathrm{I}>\mathrm{Br}>\mathrm{Cl}>\mathrm{F}$ 
APPENDIX 4: online questionnaire "Student's opinion after the use of Web 2.0 tools in Organic Chemistry courses"

This survey is anonymous and aims to know your opinion about the Web 2.0 tools after you used them in the Organic Chemistry course.

1. Organic course you are attending:

$\square$ Fundamental Organic Chemistry

Organic Chemistry I

2. Which professional career are you studying?

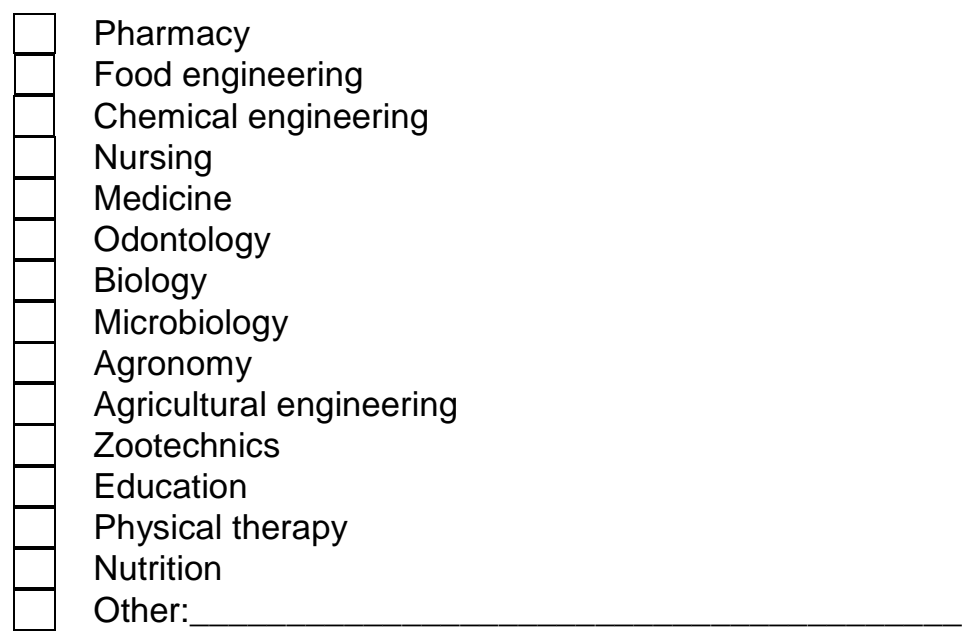

4. Age: (years)

5. Sex:

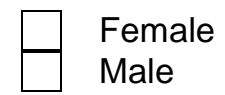

6. How easy was for you to use the Blog "http://organica-eq-ucr.blogspot.com/"?

\begin{tabular}{|l|l} 
& Very easy \\
& Easy \\
& Difficult \\
& Very difficult \\
I did not use the Blog \\
Other:
\end{tabular}

7. If you don't use the Blog, please could you tell us why?

8. Do you think the Blog helped you with the learning and understanding of the basic concepts of Organic Chemistry?

\begin{tabular}{|l|l} 
& Yes \\
& No \\
Other:
\end{tabular} 
9. How easy was for you to use the videos from the Blog?

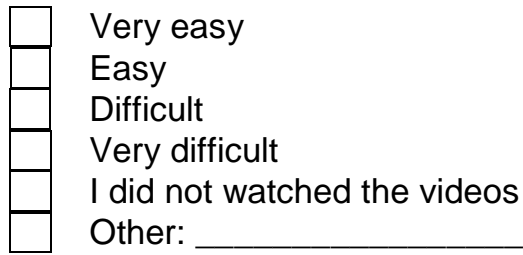

10. If you don't use the videos, please could you tell us why?

11. Do you think the videos helped you with the learning and understanding of the basic concepts of Organic Chemistry?
$\square$ Yes
No
Other:

12. Do you consider appropriate to use the Blogs and videos in education?
$\square$ Yes
$\square$ No
Other:

13. Do you think that Moodle help you with the learning and understanding of the basic concepts of Organic Chemistry?
$\square$ Yes
$\square$ No
Other:

14. Please explain your answer to the previous question:

15. Which other tools do you think could be useful in education?

Facebook

Wikis

GoogleDocs

Podcast

Twitter

Dropbox

Other:

None:

16. If you wish to make any comments regarding the Web 2.0 in the Organic Chemistry courses, please use the space below: 


\section{APPENDIX 5: Results from test 1 (diagnostic test)}

Table 1. Student ratings obtained in the diagnostic test (Test 1) before the intervention.

\begin{tabular}{lc} 
Subject & Correct answer (\%) \\
\hline Isotopes & 31 \\
Valence electrons & 93 \\
Isomers & 70 \\
Covalent bond & 87 \\
Electronic configuration & 78 \\
Sorting by electronegativity & 91 \\
Geometry of molecules & 63 \\
Oxidation state & 42 \\
Lewis structures & 21 \\
pH meaning & 25 \\
Solubility in water & 65 \\
Solubility in hexane & 42 \\
Dipole-dipole interaction & 16 \\
Hydrogen bonds & 48 \\
Acidity and basicity & 38 \\
Sodium bicarbonate basicity & 71 \\
Oxidative capacity $\quad$ of & 26 \\
Basicity of potash lye & 62 \\
Neutrality of a liquor & 28 \\
Redox capacity of zinc- & 62 \\
Orange juice acidity & 69 \\
Vinegar acidity & 80 \\
Neutrality of fuels & 37 \\
&
\end{tabular}

